\title{
Controlling the Microbiome: Microhabitat Adjustments for Successful Biocontrol Strategies in Soil and Human Gut
}

\author{
Eveline Adam ${ }^{1+}$, Anneloes E. Groenenboom ${ }^{2 \dagger}$, Viola Kurm ${ }^{3 t}$, Magdalena Rajewska ${ }^{4 t}$, \\ Ruth Schmidt ${ }^{5,6 \dagger}$, Olaf Tyc ${ }^{5,6 t}$, Simone Weidner ${ }^{7 t}$, Gabriele Berg ${ }^{1 \neq}$, Wietse de Boer ${ }^{5,6 *}$ \\ and Joana Falcão Salles ${ }^{8 \neq}$ \\ ${ }^{1}$ Institute of Environmental Biotechnology, Graz University of Technology, Graz, Austria, ${ }^{2}$ Laboratory of Genetics, \\ Wageningen University, Wageningen, Netherlands, ${ }^{3}$ Department of Terrestrial Ecology, Netherlands Institute of Ecology, The \\ Royal Netherlands Academy of Arts and Sciences, Wageningen, Netherlands, ${ }^{4}$ Laboratory of Biological Plant Protection, \\ Intercollegiate Faculty of Biotechnology, University of Gdańsk and Medical University of Gdańsk, Gdańsk, Poland, \\ ${ }^{5}$ Department of Microbial Ecology, Netherlands Institute of Ecology, The Royal Netherlands Academy of Arts and Sciences, \\ Wageningen, Netherlands, ${ }^{6}$ Department of Soil Quality, Wageningen University and Research Centre, Wageningen, \\ Netherlands, ${ }^{7}$ Department of Biology, Institute of Environmental Biology, Utrecht University, Utrecht, Netherlands, ${ }^{8}$ Institute of \\ Evolutionary Life sciences, Groningen University, Groningen, Netherlands
}

\section{OPEN ACCESS}

Edited by: Joerg Graf,

University of Connecticut, USA

Reviewed by:

Carl James Yeoman,

Montana State University, USA

Anton Hartmann,

German Research Center for Environmental Health, Germany

*Correspondence: Wietse de Boer w.deboer@nioo.knaw.nl

† Junior authors.

${ }^{\ddagger}$ Senior authors.

Specialty section: This article was submitted to

Microbial Symbioses, a section of the journal Frontiers in Microbiology

Received: 15 March 2016 Accepted: 27 June 2016 Published: 13 July 2016

Citation: Adam E, Groenenboom AE, Kurm V, Rajewska M, Schmidt R, Tyc O,

Weidner S, Berg G, de Boer W and Falcão Salles J (2016) Controlling the Microbiome: Microhabitat Adjustments for Successful Biocontrol Strategies in Soil and Human Gut.

Front. Microbiol. 7:1079.

doi: 10.3389/fmicb.2016.01079
Keywords: host beneficial bacteria, microbiome control, minor disturbances, major disturbances, synbiotics

\section{INTRODUCTION}

The human gut and the rhizosphere are environments colonized by highly diverse communities of microbes, which perform complex interactions with their host and carry out important functions including enhanced disease resistance and nutrient uptake. In humans they are involved in energy harvest and storage as well as in interactions with the immune system (Clemente et al., 2012). In plants they have profound effects on seed germination, seedling vigor, nutrition, plant health, and development of the innate immune system (Mendes et al., 2013; Berg et al., 2014a; Schikora et al., 2016). The composition of the microbial communities is host-specific and related to its health status (Smalla et al., 2001; Kinross et al., 2011; Berg et al., 2014a). Imbalances caused by disturbance-induced shifts in microbial species abundances can lead to disease outbreaks in both environments (Berendsen et al., 2012; Robles Alonso and Guarner, 2013; Berg et al., 2014b) and further to probable proliferation of pathogenic species (Van Elsas et al., 2012; Van Agtmaal et al., 2015).

To restore or maintain the health of the host, bio-based solutions supporting the pathogensuppressing ability of the hosts' native microbiome can be applied, including probiotics, synbiotics and biocontrol agents (de Vrese and Schrezenmeir, 2008). Such methods aim to increase the abundance and activity of host beneficial bacteria (HBB). However, addition of HBB does not always result in the desired pathogen suppression due to insufficient establishment, i.e., lower survival and/or poor colonization rates of the HBB (Bashan et al., 2014).

Concepts from invasion ecology suggest that survival rates of invaders are inversely related to the diversity of the native microbiome. This can be explained by higher resource uptake and consequent reduction in niche availability (Mallon et al., 2015). In addition, prevailing physical and chemical parameters in the respective environment like texture, pore size distribution, and moisture content might not favor the establishment of the introduced HBB. For a long-term establishment of the $\mathrm{HBB}$ in the soil these abiotic factors have to be considered. In the gut, the colonization resistance determined by the commensal microbiome is linked to its capacity to exploit the available niches and to prevent the establishment of invaders via niche occupation (reviewed in Stecher et al., 2013). The knowledge on mechanisms of microbial invasions (Mallon et al., 2015) can be used to improve the survival of $\mathrm{HBB}$ in both environments. 
Given that similar mechanisms drive microbial colonization and establishment in the gut and rhizosphere microbiomes, we suggest that biocontrol strategies could be similar for both environments (Ramírez-Puebla et al., 2013; Berg et al., 2015; Mendes and Raaijmakers, 2015). Here we develop possible strategies to ensure long-term establishment of HBB by manipulating niche availability.

\section{CREATING MICROHABITATS FOR HOST BENEFICIAL BACTERIA BY INTRODUCING MINOR DISTURBANCES}

Several studies have shown that soils harboring low microbial biomass or low microbial diversity are more susceptible to colonization by other organisms (Fließbach et al., 2009; Van Elsas et al., 2012). Certain agricultural practices can result in major disturbances of the rhizosphere microbiome. Examples include disinfestation with chemical pesticides, heat treatment (Stapleton, 2000), radiation or anaerobic disinfestation (Van Agtmaal et al., 2015). Moreover, tillage systems may have major effects on the established community by reducing certain soil microbial populations, particularly fungi (Ventorino et al., 2012). Analogous events, leading to changes in the human gut microbiome, are the application of broad spectrum antibiotics, fecal transplantations (Landy et al., 2011; de Vos, 2013) or considerable changes in diet (Turnbaugh et al., 2009). Whilst major disturbances are frequently used to eliminate pathogens, those methods possibly also disrupt beneficial functions of the indigenous microbial community (Altieri, 1999; Geiger et al., 2010).

An alternative strategy is to introduce minor disturbances to create free niches for HBB's in both the rhizosphere and the human gut microbiome. This strategy aims to selectively empty niches in the existing community.

In the rhizosphere the introduction of accessory bacterial predators such as protozoa (e.g., flagellates, ciliates) or nematodes (Jousset et al., 2006; Abada et al., 2009; Pedersen et al., 2009; Freyth et al., 2010; Neidig et al., 2011; Müller et al., 2013) could foster biocontrol strains via enhanced selective predation when the biocontrol strain protects itself through production of antibiotics. The increase in predation pressure might also stimulate biocontrol strategies by direct predation on pathogens as well as nutrient turnover and bacterial activity in soil. Likewise, specific bacteriophages could be applied to selectively eliminate target bacterial species or strains. This strategy has been effectively shown as part of disease management for Rhizobium sp., Bacillus sp., Burkholderia sp., Xanthomonas sp., Pectobacterium sp. and Dickeya sp. (Evans et al., 1979; Sharp et al., 1986; Lynch et al., 2012; Chae et al., 2014; Santamaría et al., 2014; Czajkowski et al., 2015). For this approach, elimination of pathogens and reduction of soil bacterial species that directly compete with the biocontrol agents (i.e., those sharing similar metabolic capacities) are desirable. Due to their specificity, bacteriophages have also been used to treat gastrointestinal infections of bacterial origin in humans (Sulakvelidze et al., 2001; Abedon et al., 2011). Moreover, they were successfully used together with bifidobacteria to treat antibiotic-associated dysbacteriosis in infants (Litvinova et al., 1978). Therefore, bacteriophages represent an alternative to selectively wipe out bacteria (either pathogens or strong competitors) in the gut and to form a niche for potential $\mathrm{HBBs}$ to thrive. In the rhizosphere the use of bacterial helper strains, an application of targeted specific antibiotics or enzymes (e.g., chitinases; Herrera-Estrella and Chet, 1999) might affect the microbiome composition sufficiently to form free niches for $\mathrm{HBB}$. Another possibility is to introduce minor changes in physical properties like $\mathrm{pH}$ value (Rousk et al., 2010), temperature (Van Veen et al., 1997; Haas and Défago, 2005), moisture dynamics or salinity (Canfora et al., 2014; Dini-Andreote et al., 2014).

Most of the methods described here apply to the rhizosphere (e.g., substantial temperature or salinity changes), but due to ethical concerns can only be considered in a limited manner for the human gut. Thus, the direct applicability to the human gut remains to be investigated. The concept of freeing/forming a microhabitat for HBB by minor disturbances in the rhizosphere or the human gut should be developed and optimized for different situations.

Apart from making an existing niche available for the HBB by removal of at least a part of the adapted community, creation of a new niche could also be taken into consideration.

\section{IMPROVEMENT OF THE ENVIRONMENT-THE HUMAN GUT AS A PARAGON FOR CONCEPTS IN BIOCONTROL}

To alleviate competition and increase the chance of establishment of HBB in an environment that harbors a highly diverse microbial community utilizing all available resources can be enabled by adding specific energy resources, for example prebiotics. Prebiotics selectively stimulate growth and/or activity of the beneficial bacteria and facilitate their establishment in the heavily colonized gut (Teitelbaum and Walker, 2002; Tuohy et al., 2003). Moreover, administration of synbiotics, a combination of a probiotic (i.e., the $\mathrm{HBB}$ ) and a prebiotic, has recently attracted attention (Schrezenmeir and de Vrese, 2001). The prebiotic provides a selective food source for the $\mathrm{HBB}$ enhancing its growth and establishment (Teitelbaum and Walker, 2002; Saulnier et al., 2008). The success of synbiotics has been demonstrated in vitro as well as in vivo (Bartosch et al., 2005; Saulnier et al., 2008). We suggest that the use of synbiotics in the human gut can serve as a paragon to enhance the establishment of HBB in the soil. In the rhizosphere the addition of a selective food source e.g., rhizopins (Oger et al., 2004) could be used to stimulate specific bacteria in the rhizosphere community.

\section{SYNBIOTICS FOR THE SOIL}

Parallels with prebiotics can be seen in the application of general resources to the soil, such as composts and green manures. These strategies have shown to be effective in the control of soilborne diseases as they combine the introduction of biocontrol 
microorganisms with organic matter after the thermophilic phase low in competition and free nutrients. This substrate favors the growth of beneficial microbes and suppresses the growth of saprophytic pathogens (Hoitink et al., 1997; Hoitink and Boehm, 1999). A disadvantage of using this method, however, is varying compost quality, which results in inconsistent colonization by biocontrol agents and subsequent effects on disease-suppression (Sturz and Christie, 2003). To ensure the presence of the desired $\mathrm{HBB}$, composts can be fortified with specific beneficial microorganisms or amended with substrates that stimulate growth and activity of a selected group of microorganisms (Haggag and Abo-Sedera, 2005; Chae et al., 2006; Dukare et al., 2011).

In addition, specific substrates and $\mathrm{HBB}$ can be combined to complement each other. Several studies have shown that certain carbon sources and minerals increase the activity of biocontrol bacteria (Duffy and Défago, 1999; Shaukat and Siddiqui, 2003; Kim et al., 2008). Moreover, plants are able to select for specific bacteria by exudation of sugars, polysaccharides, amino acids, and a variety of secondary metabolites (Teplitski et al., 2000;
Badri et al., 2009). These compounds are comparable to mucosal glycans in the human gut. As a soil synbiotic, these compounds could be artificially applied in combination with the respective HBB. Not only nutrient sources, but also signaling molecules and chemo-attractants should be taken into account, which are often highly specific for certain bacterial species or even strains. Ultimately, engineering beneficial microbes or genetically modified plants that are capable of synthesizing certain enzymes quenching bacterial signal particles might allow for shaping microbial communities against plant host pathogens (Dong et al., 2001; Ryan et al., 2009).

To support a long shelf life and stability of the product, these compounds can be formulated with specific carrier materials, membrane stabilizers and buffering agents in finetuned quantities (Paau, 1998; Bashan et al., 2014). An example for such soil inoculum carrier is biochar (charcoal used as soil amendment), known to have positive effects on soil properties such as pH (Saxena et al., 2013; Hale et al., 2014) and potentially be amended with extra HBB-specific resources.

\section{APPLICATION OF HOST BENEFICIAL BACTERIA}

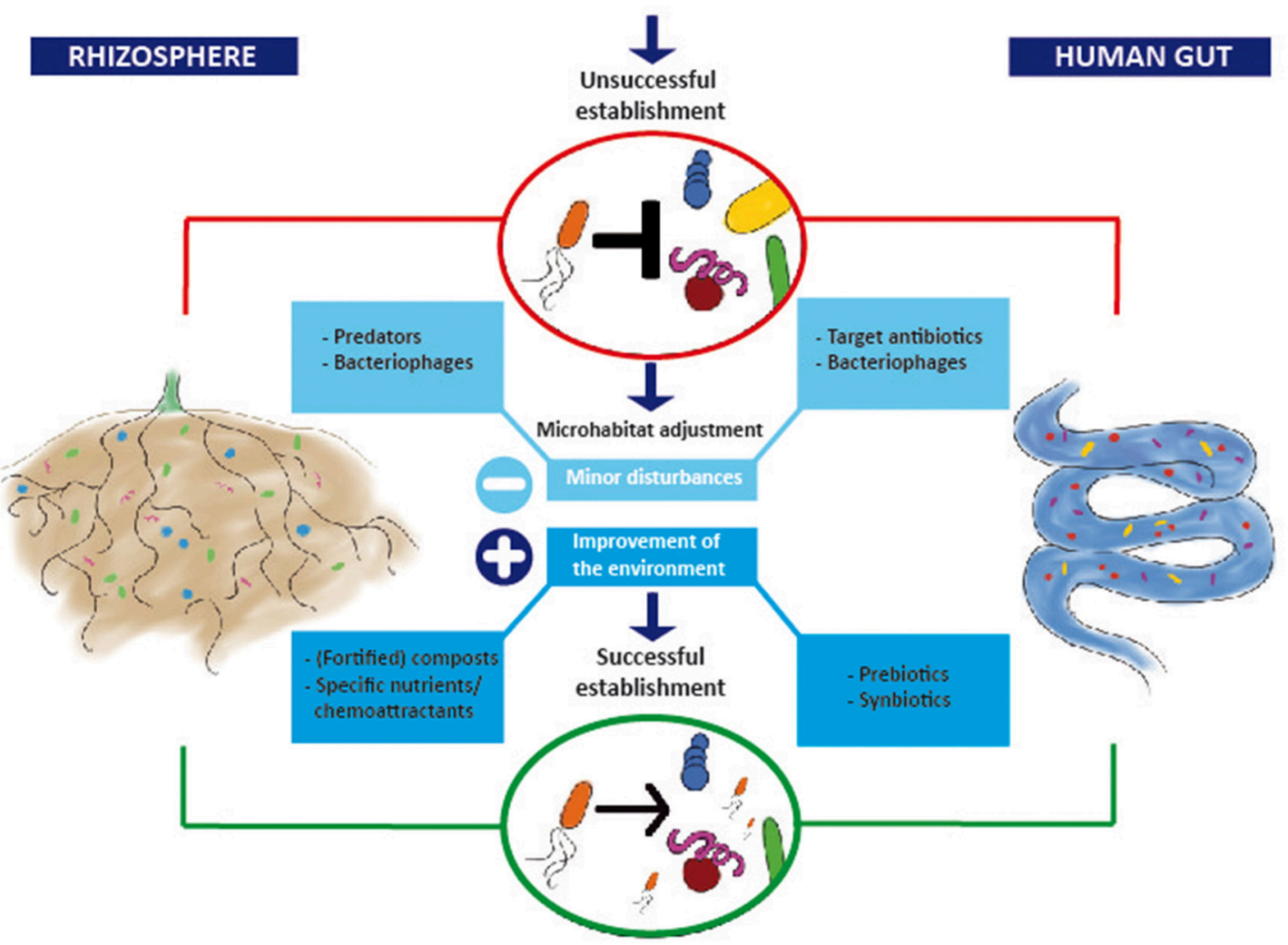

FIGURE 1 | Process of establishment of host beneficial bacteria (HBB) in the rhizosphere soil and the human gut. Application of HBB without additional measures frequently results in an unsuccessful establishment. To achieve a successful establishment of the HBB introduction of minor disturbances that empty host-associated niches in combination with improvements of the environment that create a new niche are suggested. Examples for the rhizosphere and the human gut. 


\section{UTILIZING THE SPECIFICITY OF HOST-BACTERIUM INTERACTIONS}

Selection of the appropriate crop plant or a particular bacterial genotype can significantly influence the growth and establishment of HBB in soil (Mazzola, 2004) as interactions between plant and bacterial genotypes are assumed to be highly specific. This specificity could also be used in the human gut hosting defined beneficial strains (Tap et al., 2009). This selection could counteract down-sides of synbiotics, in which the presence of the HBB usually decreases dramatically once the consumption of the prebiotic stops (Bezkorovainy, 2001). For the same reasons, enhancing indigenous soil bacteria should be considered as an alternative to introducing new strains as they are likely to be better adapted to the respective environment (Chaparro et al., 2012).

\section{OUTLOOK AND CONCLUSIONS}

In our opinion, the future of the $\mathrm{HBB}$ application lies in milder treatment of soils by using case-specific nutrient-microbe combinations as well as individualized treatments of patchy field sites after field structure analysis. As summarized in Figure 1, we suggest considering approaches such as the use of minor disturbance combined with timely application of $\mathrm{HBB}$ to improve their establishment in the soil. Soil treatments could be selected in analogy to therapies chosen for human guts. A new term "synbiotics for the rhizosphere" could reflect such intention.

It is assumed, that modern crop plants lost beneficial traits due to breeding programs conducted under conditions with high nutrient supply and the use of chemical pesticides. Consequently, breeding plants for beneficial plant-microbe interactions is an emerging research topic that might give birth to cultivars, which

\section{REFERENCES}

Abada, E. A., Sung, H., Dwivedi, M., Park, B. J., Lee, S. K., and Ahn, J. (2009). C. elegans behavior of preference choice on bacterial food. Mol. Cells 28, 209-213. doi: 10.1007/s10059-009-0124-x

Abedon, S. T., Kuhl, S. J., Blasdel, B. G., and Kutter, E. M. (2011). Phage treatment of human infections. Bacteriophage 1, 66-85. doi: 10.4161/bact.1.2. 15845

Altieri, M. A. (1999). The ecological role of biodiversity in agroecosystems. Agric. Ecosyst. Environ. 74, 19-31. doi: 10.1016/S0167-8809(99) 00028-6

Badri, D. V., Weir, T. L., van der Lelie, D., and Vivanco, J. M. (2009). Rhizosphere chemical dialogues: plant-microbe interactions. Curr. Opin. Biotechnol. 20, 642-650. doi: 10.1016/j.copbio.2009.09.014

Bartosch, S., Woodmansey, E. J., Paterson, J. C. M., McMurdo, M. E. T., and Macfarlane, G. T. (2005). Microbiological effects of consuming a synbiotic containing Bifidobacterium bifidum, Bifidobacterium lactis, and oligofructose in elderly persons, determined by real-time polymerase chain reaction and counting of viable bacteria. Clin. Infect. Dis. 40, 28-37. doi: 10.1086/4 26027

Bashan, Y., de-Bashan, L., Prabhu, S. R., and Hernandez, J.-P. (2014). Advances in plant growth-promoting bacterial inoculant technology: formulations and interact more efficiently with beneficial indigenous strains or with the applied HBB.

We see a sustainable future for agriculture by comparing methods for restoring or retaining the human gut microbiome and those altering the rhizosphere microbiome. Therefore, we suggest a paradigm shift in agricultural practices toward specialized treatment of the rhizosphere microbiomes as described in this work. We invite researchers of agricultural and human health related research areas to compare the methods of both fields and take into consideration findings of the other for their own future work.

\section{AUTHOR CONTRIBUTIONS}

The authors EA, AG, VK, MR, RS, OT, and SW contributed equally to this opinion paper. GB, WD, and JF shared senior contribution.

\section{ACKNOWLEDGMENTS}

We thank the graduate schools PE\&RC, Ecology \& Evolution, SENSE, and the organizers of the post graduate course "Microbial ecology." This course gave the authors the platform for creating the outline of this article. MR participation in the course was possible through the Mobi4Health programme, within the European Union Seventh Framework Programme FP7/20072013 under grant agreement no. 316094. SW contribution was funded by the Netherlands Organisation for Scientific Research NWO (project no. 870.15.050). EA participation through fundings of the Austrian Research Promotion Agency FFG (project no. 836466). AG participation through fundings of NOW-WOTRO. The authors thank Monique Beijaert (NIOOKNAW) who contributed to the design of the figure. This is publication 6097 of the NIOO-KNAW. practical perspectives (1998-2013). Plant Soil 378, 1-33. doi: 10.1007/s11104 013-1956-x

Berendsen, R. L., Pieterse, C. M. J., and Bakker, P. A. H. M. (2012). The rhizosphere microbiome and plant health. Trends Plant Sci. 17, 478-486. doi: 10.1016/j.tplants.2012.04.001

Berg, G., Grube, M., Schloter, M., and Smalla, K. (2014a). Unraveling the plant microbiome: looking back and future perspectives. Front. Microbiol. 5:148. doi: 10.3389/fmicb.2014.00148

Berg, G., Grube, M., Schloter, M., and Smalla, K. (2014b). The plant microbiome and its importance for plant and human health. Front. Microbiol. 5:491. doi: 10.3389/fmicb.2014.00491

Berg, G., Krause, R., and Mendes, R. (2015). Cross-kingdom similarities in microbiome ecology and biocontrol of pathogens. Front. Microbiol. 6:1311. doi: 10.3389/fmicb.2015.01311

Bezkorovainy, A. (2001). Probiotics: determinants of survival and growth in the gut. Am. J. Clin. Nutr. 73(2 suppl.), 399S-405S.

Canfora, L., Bacci, G., Pinzari, F., Lo Papa, G., Dazzi, C., and Benedetti, A. (2014). Salinity and bacterial diversity: to what extent does the concentration of salt affect the bacterial community in a saline soil? PLoS ONE 9:e106662. doi: 10.1371/journal.pone.0106662

Chae, D. H., De Jin, R., Hwangbo, H., Kim, Y. W., Kim, Y. C., Park, R. D., et al. (2006). Control of late blight (Phytophthora capsici) in pepper plant with a 
compost containing multitude of chitinase-producing bacteria. BioControl 51, 339-351. doi: 10.1007/s10526-005-2934-x

Chae, J.-C., Hung, N. B., Yu, S.-M., Lee, H. K., and Lee, Y. H. (2014). Diversity of bacteriophages infecting Xanthomonas oryzae pv. oryzae in paddy fields and its potential to control bacterial leaf blight of rice. J. Microbiol. Biotechnol. 24, 740-747. doi: 10.4014/jmb.1402.02013

Chaparro, J. M., Sheflin, A. M., Manter, D. K., and Vivanco, J. M. (2012). Manipulating the soil microbiome to increase soil health and plant fertility. Biol. Fertil. Soils 48, 489-499. doi: 10.1007/s00374-012-0691-4

Clemente, J. C., Ursell, L. K., Parfrey, L. W., and Knight, R. (2012). The impact of the gut microbiota on human health: an integrative view. Cell 148, 1258-1270. doi: 10.1016/j.cell.2012.01.035

Czajkowski, R., Ozymko, Z., de Jager, V., Siwinska, J., Smolarska, A., Ossowicki, A., et al. (2015). Genomic, proteomic and morphological characterization of two novel broad host lytic bacteriophages $\Phi$ PD10.3 and $\Phi$ PD23.1 infecting pectinolytic Pectobacterium spp. and Dickeya spp. PLoS ONE 10:e0119812. doi: 10.1371/journal.pone.0119812

de Vos, W. M. (2013). Fame and future of faecal transplantations - developing next-generation therapies with synthetic microbiomes. Microb. Biotechnol. 6, 316-325. doi: 10.1111/1751-7915.12047

de Vrese, M., and Schrezenmeir, J. (2008). Probiotics, prebiotics, and synbiotics. Adv. Biochem. Eng. Biotechnol. 111, 1-66. doi: 10.1007/10_2008_097

Dini-Andreote, F., de Cassia Pereira e Silva, M., Triado-Margarit, X., Casamayor, E. O., van Elsas, J. D., and Falcao Salles, J. (2014). Dynamics of bacterial community succession in a salt marsh chronosequence: evidences for temporal niche partitioning. ISME J. 8, 1989-2001. doi: 10.1038/ismej.2014.54

Dong, Y. H., Wang, L. H., Xu, J. L., Zhang, H. B., Zhang, X. F., and Zhang, L. H. (2001). Quenching quorum-sensing-dependent bacterial infection by an $N$-acyl homoserine lactonase. Nature 411, 813-817. doi: 10.1038/35081101

Duffy, B. K., and Défago, G. (1999). Environmental factors modulating antibiotic and siderophore biosynthesis by Pseudomonas fluorescens biocontrol strains. Appl. Environ. Microbiol. 65, 2429-2438

Dukare, A. S., Prasanna, R., Chandra Dubey, S., Nain, L., Chaudhary, V., Singh, R., et al. (2011). Evaluating novel microbe amended composts as biocontrol agents in tomato. Crop Prot. 30, 436-442. doi: 10.1016/j.cropro.2010.12.017

Evans, J., Barnet, Y. M., and Vincent, J. M. (1979). Effect of a bacteriophage on colonization and nodulation of clover roots by paired strains of Rhizobium trifolii. Can. J. Microbiol. 25, 974-978. doi: 10.1139/m79-149

Fließbach, A., Winkler, M., Lutz, M. P., Oberholzer, H.-R., and Mäder, P. (2009). Soil amendment with Pseudomonas fluorescens CHA0: lasting effects on soil biological properties in soils low in microbial biomass and activity. Microb. Ecol. 57, 611-623. doi: 10.1007/s00248-009-9489-9

Freyth, K., Janowitz, T., Nunes, F., Voss, M., Heinick, A., Bertaux, J., et al. (2010). Reproductive fitness and dietary choice behavior of the genetic model organism Caenorhabditis elegans under semi-natural conditions. Mol. Cells 30, 347-353. doi: 10.1007/s10059-010-0125-9

Geiger, F., Bengtsson, J., Berendse, F., Weisser, W. W., Emmerson, M., Morales, M. B., et al. (2010). Persistent negative effects of pesticides on biodiversity and biological control potential on European farmland. Basic Appl. Ecol. 11, 97-105. doi: 10.1016/j.baae.2009.12.001

Haas, D., and Défago, G. (2005). Biological control of soil-borne pathogens by fluorescent pseudomonads. Nat. Rev. Microbiol. 3, 307-319. doi: $10.1038 /$ nrmicro1129

Haggag, W. M., and Abo-Sedera, S. A. (2005). Characteristics of three Trichoderma species in peanut haulmscompost involved in biocontrol of cumin wilt disease. Int. J. Agric. Biol. 7, 222-229.

Hale, L., Luth, M., and Crowley, D. (2014). Biochar characteristics relate to its utility as an alternative soil inoculum carrier to peat and vermiculite. Soil Biol. Biochem. 81, 228-235. doi: 10.1016/j.soilbio.2014.11.023

Herrera-Estrella, A., and Chet, I. (1999). "Chitinases in biological control," in Chitin and Chitinases, eds P. Jolles and R. A. A. Muzzarelli (Basel: Birkhäuser Publishing), 171-184.

Hoitink, H. A. J., and Boehm, M. J. (1999). Biocontrol within the context of soil microbial communities: a substrate-dependent phenomenon. Annu. Rev. Phytopathol. 37, 427-446. doi: 10.1146/annurev.phyto.37.1.427

Hoitink, H. A. J., Stone, A. G., and Han, D. Y. (1997). Suppression of plant diseases by composts. HortScience 32, 184-187

Jousset, A., Lara, E., Wall, L. G., and Valverde, C. (2006). Secondary metabolites help biocontrol strains Pseudomonas fluorescens CHA0 to escape protozoan grazing. Appl. Environ. Microbiol. 72, 7083-7090. doi: 10.1128/AEM.00 557-06

Kim, Y., Jung, H., Kim, K., and Park, S. (2008). An effective biocontrol bioformulation against Phytophthora blight of pepper using growth mixtures of combined chitinolytic bacteria under different field conditions. Eur. J. Plant Pathol. 120, 373-382. doi: 10.1007/s10658-007-9227-4

Kinross, J. M., Darzi, A. W., and Nicholson, J. K. (2011). Gut microbiome-host interactions in health and disease. Genome Med. 3, 1-12. doi: 10.1186/gm228

Landy, J., Al-Hassi, H. O., McLaughlin, S. D., Walker, A. W., Ciclitira, P. J., Nicholls, R. J., et al. (2011). Review article: faecal transplantation therapy for gastrointestinal disease. Aliment. Pharmacol. Ther. 34, 409-415. doi: 10.1111/j.1365-2036.2011.04737.x

Litvinova, A. M., Chtetsova, V. M., and Kavtreva, I. G. (1978). Evaluation of efficacy of the use of coli-Proteus bacteriophage in intestinal dysbacteriosis in premature infants. Vopr. Okhr. Materin. Det. 23, 42-44

Lynch, K. H., Stothard, P., and Dennis, J. J. (2012). Comparative analysis of two phenotypically-similar but genomically-distinct Burkholderia cenocepaciaspecific bacteriophages. BMC Genomics 13:223. doi: 10.1186/1471-2164$13-223$

Mallon, C. A., van Elsas, J. D., and Salles, J. F. (2015). Microbial invasions: the process, patterns, and mechanisms. Trends Microbiol. 23, 719-729. doi: 10.1016/j.tim.2015.07.013

Mazzola, M. (2004). Assessment and management of soil microbial community structure for disease suppression. Annu. Rev. Phytopathol. 42, 35-59. doi: 10.1146/annurev.phyto.42.040803.140408

Mendes, R., Garbeva, P., and Raaijmakers, J. M. (2013). The rhizosphere microbiome: significance of plant beneficial, plant pathogenic, and human pathogenic microorganisms. FEMS Microbiol. Rev. 37, 634-663. doi: $10.1111 / 1574-6976.12028$

Mendes, R., and Raaijmakers, J. M. (2015). Cross-kingdom similarities in microbiome functions. ISME J. 9, 1905-1907. doi: 10.1038/ismej.2015.7

Müller, M. S., Scheu, S., and Jousset, A. (2013). Protozoa drive the dynamics of culturable biocontrol bacterial communities. PLOS ONE 8:e66200. doi: 10.1371/journal.pone.0066200

Neidig, N., Paul, R. J., Scheu, S., and Jousset, A. (2011). Secondary metabolites of Pseudomonas fluorescens CHA0 drive complex non-trophic interactions with bacterivorous nematodes. Microb. Ecol. 61, 853-859. doi: 10.1007/s00248-0119821-Z

Oger, P. M., Mansoure, H., Nese, X., and Dessaux, Y. (2004). Engineering root exudation of Lotus toward the production of two novel carbon compounds leads to the selection of distinct microbial populations in the rhizosphere. Microb. Ecol. 47, 96-103. doi: 10.1007/s00248-003-2012-9

Paau, A. (1998). "Formulation of beneficial organisms applied to soil," in Formulation of Microbial Biopesticides, ed H. D. Burges (Dordrecht: Kluwer Academic Publishers), 235-254.

Pedersen, A. L., Nybroe, O., Winding, A., Ekelund, F., and Bjornlund, L. (2009). Bacterial feeders, the nematodes Caenorhabditis elegans and the flagellate Cercomonas longicauda, have different effects on outcome of competition among the Pseudomonas biocontrol strains CHA0 and DSS73. Microb. Ecol. 57, 501-509. doi: 10.1007/s00248-008-9455-y

Ramírez-Puebla, S. T., Servín-Garcidueñas, L. E., Jiménez-Marín, B., Bolaños, L. M., Rosenblueth, M., Martínez, J., et al. (2013). Gut and root microbiota commonalities. Appl. Environ. Microbiol. 79, 2-9. doi: 10.1128/AEM. 02553-12

Robles Alonso, V., and Guarner, F. (2013). Linking the gut microbiota to human health. Br. J. Nutr. 109, 21-26. doi: 10.1017/S0007114512005235

Rousk, J., Bååth, E., Brookes, P. C., Lauber, C. L., Lozupone, C., Caporaso, J. G., et al. (2010). Soil bacterial and fungal communities across a $\mathrm{pH}$ gradient in an arable soil. ISME J. 4, 1340-1351. doi: 10.1038/ismej.2010.58

Ryan, P. R., Dessaux, Y., Thomashow, L. S., and Weller, D. M. (2009). Rhizosphere engineering and management for sustainable agriculture. Plant Soil 321, 363-383. doi: 10.1007/s11104-009-0001-6

Santamaría, R. I., Bustos, P., Sepúlveda-Robles, O., Lozano, L., Rodríguez, C., Fernández, J. L., et al. (2014). Narrow-host-range bacteriophages that infect Rhizobium etli associate with distinct genomic types. Appl. Environ. Microbiol. 80, 446-454. doi: 10.1128/AEM.02256-13

Saulnier, D. M. A., Gibson, G. R., and Kolida, S. (2008). In vitro effects of selected synbiotics on the human faecal microbiota composition. FEMS Microbiol. Ecol. 66, 516-527. doi: 10.1111/j.1574-6941.2008.00561.x 
Saxena, J., Rana, G., and Pandey, M. (2013). Impact of addition of biochar along with Bacillus sp. on growth and yield of French beans. Sci. Hortic. 162, 351-356. doi: 10.1016/j.scienta.2013.08.002

Schikora, A., Schenk, S. T., and Hartmann, A. (2016). Beneficial effects of bacteriaplant communication based on quorum sensing molecules of the $N$-acyl homoserine lactone group. Plant Mol. Biol. 90, 605-612. doi: 10.1007/s11103016-0457-8

Schrezenmeir, J., and de Vrese, M. (2001). Probiotics, prebiotics, and synbioticsapproaching a definition. Am. J. Clin. Nutr. 73(suppl.), 361S-364S.

Sharp, R. J., Ahmad, S. I., Munster, A., Dowsett, B., and Atkinson, T. (1986). The isolation and characterization of bacteriophages infecting obligately thermophilic strains of Bacillus. J. Gen. Microbiol. 132, 1709-1722 doi: 10.1099/00221287-132-6-1709

Shaukat, S. S., and Siddiqui, I. A. (2003). The influence of mineral and carbon sources on biological control of charcoal rot fungus, Macrophomina phaseolina by fluorescent pseudomonads in tomato. Lett. Appl. Microbiol. 36, 392-398. doi: 10.1046/j.1472-765X.2003.01325.x

Smalla, K., Wieland, G., Buchner, A., Zock, A., Parzy, J., Kaiser, S., et al. (2001). Bulk and rhizosphere soil bacterial communities studied by denaturing gradient gel electrophoresis: plant-dependent enrichment and seasonal shifts revealed. Appl. Environ. Microbiol. 67, 4742-4751. doi: 10.1128/AEM.67.10.47424751.2001

Stapleton, J. J. (2000). Soil solarization in various agricultural production systems. Crop Prot. 19, 837-841. doi: 10.1016/S0261-2194(00)00111-3

Stecher, B., Berry, D., and Loy, A. (2013). Colonization resistance and microbial ecophysiology: using gnotobiotic mouse models and single-cell technology to explore the intestinal jungle. FEMS Microbiol. Rev. 37, 793-829. doi: 10.1111/1574-6976.12024

Sturz, A. V., and Christie, B. R. (2003). Beneficial microbial allelopathies in the root zone: the management of soil quality and plant disease with rhizobacteria. Soil Tillage Res. 72, 107-123. doi: 10.1016/S0167-1987(03)00082-5

Sulakvelidze, A., Alavidze, Z., and Morris, J. G. Jr. (2001). Bacteriophage therapy. Antimicrob. Agents Chemother. 45, 649-659. doi: 10.1128/AAC.45.3.649659.2001

Tap, J., Mondot, S., Levenez, F., Pelletier, E., Caron, C., Furet, J.-P., et al. (2009). Towards the human intestinal microbiota phylogenetic core. Environ. Microbiol. 11, 2574-2584. doi: 10.1111/j.1462-2920.2009.01982.x

Teitelbaum, J. E., and Walker, W. A. (2002). Nutritional impact of pre- and probiotics as protective gastrointestinal organisms. Annu. Rev. Nutr. 22, 107-138. doi: 10.1146/annurev.nutr.22.110901.145412
Teplitski, M., Robinson, J. B., and Bauer, W. D. (2000). Plants secrete substances that mimic bacterial $\mathrm{N}$-acyl homoserine lactone signal activities and affect population density-dependent behaviors in associated bacteria. Mol. Plant Microbe. Interact. 13, 637-648. doi: 10.1094/MPMI.2000.13. 6.637

Tuohy, K. M., Probert, H. M., Smejkal, C. W., and Gibson, G. R. (2003). Using probiotics and prebiotics to improve gut health. Drug Discov. Today 8, 692-700. doi: 10.1016/S1359-6446(03)02746-6

Turnbaugh, P. J., Ridaura, V. K., Faith, J. J., Rey, F. E., Knight, R., and Gordon, J. I. (2009). The effect of diet on the human gut microbiome: a metagenomic analysis in humanized gnotobiotic mice. Sci. Transl. Med. 1, 6ra14. doi: 10.1126/scitranslmed.3000322

Van Agtmaal, M., van Os, G., Hol, G., Hundscheid, M., Runia, W., Hordijk, C., et al. (2015). Legacy effects of anaerobic soil disinfestation on soil bacterial community composition and production of pathogen-suppressing volatiles. Front. Microbiol. 6:701. doi: 10.3389/fmicb.2015.00701

Van Elsas, J. D., Chiurazzi, M., Mallon, C. A., Elhottovā, D., Krištůfek, V., and Salles, J. F. (2012). Microbial diversity determines the invasion of soil by a bacterial pathogen. Proc. Natl. Acad. Sci. 109, 1159 -1164. doi: 10.1073/pnas.1109326109

Van Veen, J. A., van Overbeek, L. S., and van Elsas, J. D. (1997). Fate and activity of microorganisms introduced into soil. Microbiol. Mol. Biol. Rev. 61, 121-135

Ventorino, V., De Marco, A., Pepe, O., De Santo, A. V., and Moschetti, G. (2012). "Impact of innovative agricultural practices of carbon sequestration on soil microbial community," in Carbon Sequestration in Agricultural Soils: a multidisciplinary approach to innovative methods, ed A. Piccolo (Heidelberg: Springer-Verlag), 145-177.

Conflict of Interest Statement: The authors declare that the research was conducted in the absence of any commercial or financial relationships that could be construed as a potential conflict of interest.

Copyright (C) 2016 Adam, Groenenboom, Kurm, Rajewska, Schmidt, Tyc, Weidner, Berg, de Boer and Falcão Salles. This is an open-access article distributed under the terms of the Creative Commons Attribution License (CC BY). The use, distribution or reproduction in other forums is permitted, provided the original author (s) or licensor are credited and that the original publication in this journal is cited, in accordance with accepted academic practice. No use, distribution or reproduction is permitted which does not comply with these terms. 